\title{
Small Retail Enterprises (SREs) and Their Role in Building Neighborhood Community in India
}

\author{
Dr. Sanjeev Bansal * and Pankaj Kumar ** \\ *Associate Professor, ** Ph.D. Scholar (Management),
}

\begin{abstract}
In India, small retailers dominated the retail industry. In the past few decades, small retailers have been straggling for market share as there is seen a huge development in customer needs and change in life style of consumer drastically. At present when foreign investors are increasing day by day in modern retailing, local small retailers need to be more attentive in responding to present day competition and market changes if they want to maintain their existence in this change. Many researchers say that small retailers are declining in India as powerful retail giants (supermarkets, hypermarkets, etc) taking over the marketplace. But the report published by A T Kearney demonstrates that $92 \%$ of the retail industry is still controlled by small family-run business while only $8 \%$ of the market is captured by big retailers (Kearney 2012). This paper therefore, aims to discuss the small retailers and their role in building neighborhood community in India.
\end{abstract}

\section{Introduction}

Retailing is one of the largest industries and it is a huge source of employment. It is also one of the pillars of Indian economy and accounts for 14 to 15\% of its GDP (McKinsey and Company 2007). Indian retail market has more the 14 million outlets, with that it became the largest outlet destiny in the world (Sinha and Uniyal 2007). According to A. T. Kearny India has been identified as the fifth most attractive retail destination globally from the thirty emerging markets (US-based global management consulting firm A T Kearny 2012). The report demonstrates that the share of retail sector in Indian market is Rs. 2850055 crore ( $\$ 516$ billion) in 2012. It also states that India will remain a high potential market with accelerated retail growth of 15-20 percent over the next five years expectedly.

\section{Retailing}

The word "retailing" has its origins in the French verb "retailer" which means "to cut up", and refers to one of the fundamental retailing activities which is to buy in larger quantities and sell in smaller quantities. According to William J. Stantons, "A retailer or retail store is a business enterprise which sells primarily to the ultimate consumers for non-business use". ${ }^{1}$ Cundiff and Still defines it as "Retailing consists of those activities involved in the selling directly to ultimate consumers". ${ }^{2}$ In 2004, The High Court of Delhi defined the term 'retail' as a sale for final consumption in contrast to a sale for further sale or processing, a sale to the ultimate consumer.

Retailing involves a direct interface with the customer and the coordination of business activities from end to end- right from the concept or design stage of a product or offering, to its delivery and post-delivery service to the customer. The industry has contributed to the economic growth of many countries and is undoubtedly one of the fastest changing and dynamic industries in the world today.

Indian retail industry is generally divided into two categories: Small Retail and Organized Retail.

\section{Organized Retailing:}

Organized Retailing refers to marketing activities undertaken by licensed retailers who are registered for sales tax, income tax and, whose business is corporate, who implement management techniques managed by professionals as a firm or limited company or cooperative. These include corporate-backed hypermarkets and retail chains, and also privately-owned large retail businesses. Hence, organized retail which now constitutes $8 \%$ of the total retail sector is growing at much faster pace of $45-50 \%$ per annum than small retail as per the findings of Indian Council for Research on International Economic Relations (ICRIER 2008).

\section{Unorganized Retailing:}

Unorganized Retail refers to the traditional forms of low cost retailing like local Kirana Shops Owner Operated General Stores, Convenience Stores and Street Vendors, etc. According to the report of A. T. Kearny the Unorganized Retail sector is growing at about 10\% per annum has risen from US\$ 309 billion in 2006-07 to US\$ 475 billion in 2011-12 which is approximately $92 \%$ of total retail market share (2012). This is continuously decreasing (in percentage) from previous years as shown in table: 


\begin{tabular}{|c|c|c|c|c|c|}
\hline \multicolumn{7}{|c|}{ The Shape of Indian Retail Market } \\
\hline Year & Small Retail (In billions) & $\begin{array}{c}\text { Organized Retail } \\
\text { (In billions) }\end{array}$ & $\begin{array}{c}\text { Total (In } \\
\text { billions) }\end{array}$ & $\begin{array}{c}\text { Share of Organized Retail } \\
\text { (In \%) }\end{array}$ & $\begin{array}{c}\text { Share of Small } \\
\text { Retail (In \%) }\end{array}$ \\
\hline 2007 & 322 & 15 & 337 & 4 & 96 \\
\hline 2008 & 344 & 19 & 363 & 5 & 95 \\
\hline 2009 & 368 & 22 & 390 & 6 & 94 \\
\hline 2010 & 394 & 27 & 421 & 6 & 94 \\
\hline 2011 & 422 & 33 & 455 & 7 & 93 \\
\hline 2012 & 475 & 41 & 516 & 8 & 92 \\
\hline
\end{tabular}

Source: A. T. Kearny 2007 to 2012

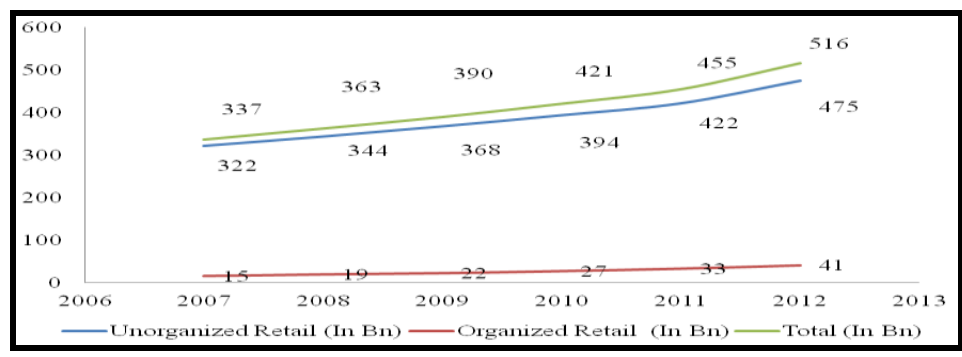

\section{Small Retail Sector In India}

To define "retailing" and "small", a generally accepted definition of retailing is "the activities involved in selling goods and services to ultimate consumers for personal consumption" (Coughlan, Anderson, Stern and El-Ansary 2001). So the articles in this review cover retailers of goods or services. The second criterion is "small", defined by the U.S. Small Business Administration (SBA) as a retailer that is "independently owned and operated but is not dominant" in its field of operation (SBA 2006). However, many reviewed articles did not report specifically on these criteria. Several terms are used to signify small retailers, including small, independent, mom-and-pop, single store and sole-proprietor. The small retail sector can be divided into following categories:

\section{Categories Of Small Retailers}

$\checkmark \quad$ Fruit \& vegetable sellers - Sells fruits and vegetables.

$\checkmark \quad$ Food stores - Result of bakery products. Also sells dairy and processed food and beverages.

$\checkmark$ Non-Vegetable Store - Sells chicken and mutton.

$\checkmark \quad$ Kirana I - Sells bakery products, dairy and processed food, home and personal care and beverages.

$\checkmark \quad$ Kirana II - Sells categories available at a kirana - I store plus cereals, pulses, spices and edible oils.

$\checkmark$ Apparel - Sells men's wear, women's wear, innerwear, kinds \& infant wear.

$\checkmark$ Footwear - Sells men's wear, women's wear, kid's wear

$\checkmark$ Customer durables \& IT-Sells electronics, durables \& IT products.

$\checkmark \quad$ Furnishing - Sells home lines \& upholstery.

$\checkmark$ Hardware - Sells sanitary ware, door fitting and tiles.

$\checkmark$ General mechanize - Includes lighting, stationery, toys, gifts \& crockery.

$\sqrt{ }$

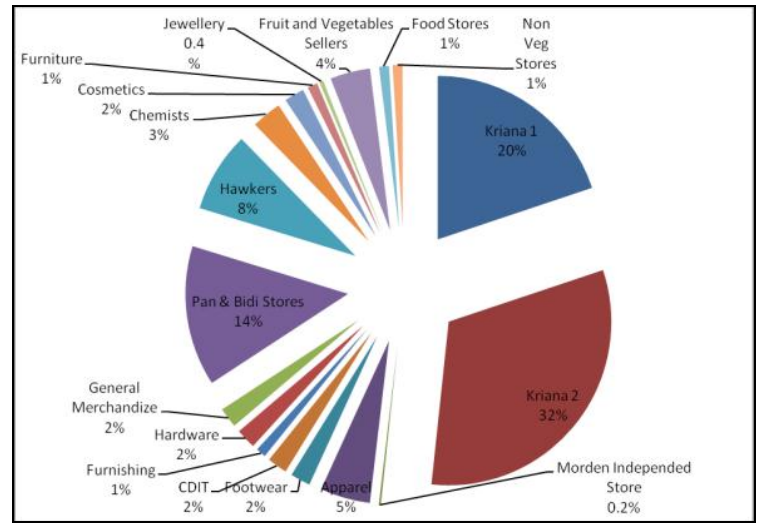

Source: http://www.technopak.com/Retail/resources.aspx 


\section{Objectives of Study}

$\checkmark$ To review the economic role of small retail enterprises.

$\checkmark$ To review the Social role of small retail enterprises.

\section{Data And Research Methodology}

The descriptive research methodology has been used to collect the data. To evaluate the overall Social and Economic role of small retailers in India, secondary data has been collected from various published sources and websites.

\section{Role of Small Retail Enterprises in India}

The following evidence shows that the small and independent retail enterprises are very important for the social and economic health of society.

Economic Role: With huge growth potential, Indian retail industry has been touted as one of the sunrise sectors. According to the Investment Commission of India, by 2015 the retail sector would have grown to $\$ 660$ billion. But here we are concern with role of small retail players in India economy. Unfortunately, the evidence is limited. One source of recent evidence on the role of the small sector in trade is a recent survey report from the National Sample Survey Organization relating to 2010-11, which provides information on both employment and gross value added in enterprises engaged in trade. It also provides information on certain structural features of these enterprises.

Data on aggregate value added in trade, covering both the organized and unorganized sector is estimated and included in the National Accounts Statistics for that year. And employment in the trading sector as a whole is available for 2009-10 from the large sample survey on employment and unemployment conducted by the NSS. What emerges from these data sources is that the unorganized sector in trade accounts for more than three-fourths (78.1 per cent) of employment in the sector as a whole in the country.

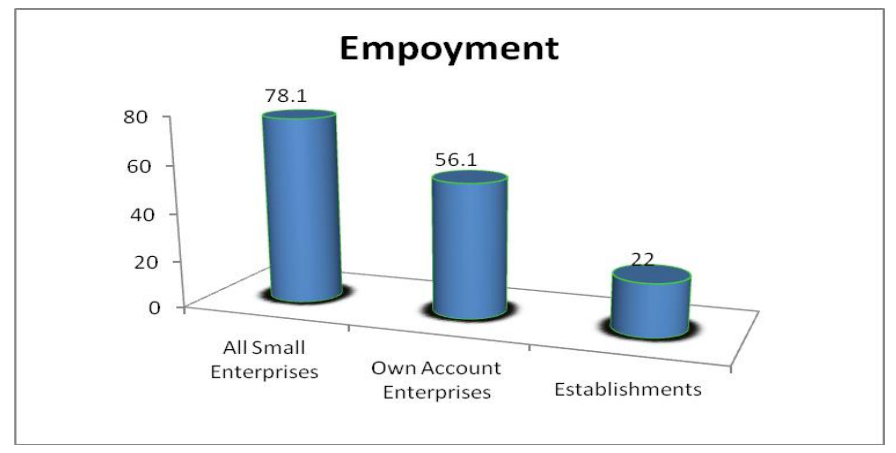

On the other hand, gross value added in the small enterprises engaged in trade amounts to just 22 per cent of the value added in the trading sector as a whole in the country. Thus, the small trading sector does indeed provide for employment for a substantial majority engaged in the sector, though with net earnings that is clearly very much lower than in the organized sector.

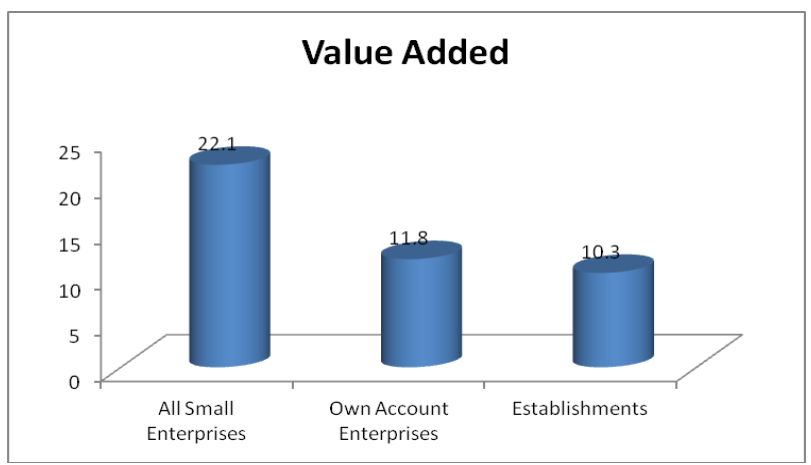

Instead of these major benefits small retail enterprises are also playing the role of local economy builders. Some of its benefits to local economies are:

Local Employment: One of the most personal advantages of businesses in the local economy is the boost in employment in the region. Employment levels influence a range of other standard-of-living metrics, such as disposable income, home foreclosure rates and new small business startups. Employing people in the local 
community can stimulate word-of-mouth advertising for a company as well, assuming the company treats its employees well enough to get positive mentions.

Local Tax Income: Businesses pay a significant portion of all taxes in the India, including income tax, property tax and employment tax. Having more businesses in the local economy can boost tax income for local governments, bringing in more money to repair roads, develop schools and improve public services.

Keeping money in the Local Economy: Compared to chain stores, locally owned businesses recycle a much larger share of their revenue back into the local economy, enriching the whole community.

Access to Services: Along with the standard-of-living increases inherent in raising local employment, the presence of the many business types can raise the standard-of-living further by providing a wider range of services and amenities within the local area. Adding a cinema to a small town, as an example, can add an entertainment choice to local residents while bringing in money from outlying communities.

\section{Social Role:}

From a social perspective, large retailers are those who have only the objective to maximize profit from the society, but not necessarily ones that contributes to community fabric. Small retailers contribute not only to the economy and but also to the society as they are playing both roles as employers in local communities and place identifiers on the landscape. For instance, there is evidence that they retain more money spent in the community and employ more people per rupee spent. And while it certainly would be unique to each business, ownership and personal investment usually associates with the personable and conscientious service. Small business owners may also be more likely to be part of the social fabric of a community, donating to local causes and volunteering their time. There are some benefits for the society, these are:

Developing personal relationships with society- Small businesses are well placed to create personal relationships with customers, employees, and suppliers. With a small business you recognize whom you're dealing with; you'll put a face" to the person you're in touch with. Person-to-person interaction is as essential as ever in building strong relationships.

Locally Made Goods: Small businesses generally offer local made products. If you have a product that you simply wish to sell, like produce, you will realize a neighborhood farmers' market that may permit you to sell it. A chain store may purchase all of its products from local manufacturers whereas you'll sell yours right close to your home. Because of this, people within the local economy are able to sell their product and services at a local Business, which is in the favor of everyone in the society.

Loyal Customers: Retailers with local focus have the benefit of producing loyal customer support, especially when theirs services are not pressured by large retail stores in the area. The strong customer base can ensures a certain level of financial sustainability, and helps the small retailers to maintain their good well, which can drive more people to the store.

Uniqueness and personal connection: It is the small businesses that define our sense of community and local character. Marshall notes that small businesses are one of those forces that actually "produce a place." They are what make each place unique - from smosa's with allu sambhar in Patiala to "lane of parantha-makers" market in New Delhi - these are the businesses that shape urban experiences and break the monotony of strip malls and shopping points populated with the same array of chain and franchise establishments. Their rarity and personal connection is what makes them special.

Development of locality: When consumers support local small businesses, they are essentially giving money back to their local society. A successful local business will generate high levels of revenue, which means that the business will pay higher taxes, including local taxes. This money is then used for development of the locality and the society.

\section{Conclusion}

Small retailers contribute not only to the economy and but also to the society as they are playing both roles as employers in local communities and place identifiers on the landscape. As small retail enterprises offer numerous positive externalities like:

$\checkmark \quad$ More money stays in the Society

$\checkmark \quad$ More jobs are created

$\checkmark \quad$ They often offer friendship, going-the-distance, service

$\checkmark \quad$ They are usually more involved in supporting community initiatives

$\checkmark \quad$ Provide a stronger sense of place and community and

$\checkmark$ There are possibly some environmental benefits associated with them.

We must go beyond the price war between the small and large retailers that can be saved by shopping at the large retail stores and help the small retailer to exist in the business. If we accept that small businesses and retail establishments have all these positive externalities. 


\section{Bibliography}

[1]. Jain, Ashok. Principles of Marketing. New Delhi: V.K. Global Publications Pvt. Ltd., 2010. P 80

[2]. Joseph, M. Soundararajan, N. Gupta, M. and Sahu, S. "Impact of Organized Retailing on the Unorganized Sector, Working Paper. 222 " Indian Council for Research on International Economic Relation, 2008

[3]. McKinsey and Company. "The Bird of Gold - The Rise of India's Consumer Market" May 2007.

[4]. Sinha, P.K. and Uniyal, D.P. Managing Retailing. New Delhi: Oxford University Press, 2007.

[5]. Small Business Administration Guide to SBA's Definitions of Small Business, 2006 (retrieved from http://www.sba.gov/gopher/FinancialAssistance/Define/defi4.txt)

[6]. Thenmozhi, S.P. and .Dhemapaul, D. "Unorganized Retailing in India - A Study on Retail Service Quality" European Journal of Social Sciences 23 (2011):71-78

[7]. Tyagi, C.L. and Kumar, Arun in Sales Management. New Delhi: Atlantic Publishers \& Distributers, 2004. P 140

[8]. Marshall, A. "How cities work: suburbs, sprawl, and the roads not taken" TX: University of Texas Press, Austin (2001): 18.

\section{Key Websites}
* http://www.sciencedirect.com
* http://www.wikipedia.org
\# http://www.scribd.com
\# http://www.technopak.com/Retail/resources.aspx
* http://www.atkearney.com 